\title{
Metabolic studies and autonomic function in children with partial lipodystrophy
}

\author{
R. J. WEST, AUDREY S. FOSBROOKE, and JUNE K. LLOYD \\ From the Department of Child Health, Institute of Child Health, University of London
}

\begin{abstract}
West, R. J., Fosbrooke, A. S., and Lloyd, J. K. (1974). Archives of Disease in Childhood, 49,627. Metabolic studies and autonomic function in children with partial lipodystrophy. Studies of carbohydrate metabolism in 6 children with partial lipodystrophy (none of whom had evidence of renal disease) showed raised fasting serum insulin concentrations. In 4 of the children hyperinsulinaemia was found after oral glucose. Plasma glucose levels within the normal range in all tests indicated that the hyperinsulinaemia was due to insulin resistance. Plasma growth hormone concentration was normal in all children, and plasma cortisol concentration was normal in 5 . Concentrations of plasma nonesterified fatty acid (NEFA), serum triglyceride, and cholesterol in fasting blood were normal. Adipose tissue from nondystrophic areas showed an increased proportion of palmitoleic acid. No abnormality of the autonomic nervous system was found. Treatment of 2 patients with propranolol did not improve their lipodystrophy.

The metabolic abnormalities present at an early age of the disease show that partial lipodystrophy should not be regarded only as a cosmetic disorder.
\end{abstract}

Partial lipodystrophy has been defined by Senior and Gellis (1964) as a symmetrical absence of facial fat, with or without the disappearance of fat from the arms, chest, abdomen, and hips, but with retention of distal subcutaneous fat. A variety of associated disorders have been described, and though in many cases the association may be fortuitous, some form of renal disease has been reported in as many as 25 to $30 \%$ of patients (Senior and Gellis, 1964).

The onset is usually in childhood, and girls are affected about four times more frequently than boys. The loss of subcutaneous adipose tissue from the upper body occurs over the space of a few months to a year or 2, but thereafter there is no further progression. There is no known treatment and spontaneous recovery seems to be rare; in 1 of the cases reported by Eisinger, Shortland, and Moorhead (1972) the lipodystrophy remitted after 8 years, though the associated nephritis persisted.

The aetiology is not known. Because of the distribution and because transplanted adipose tissue assumes the characteristics of the area into which it is placed (Langhof and Zabel, 1960), it has been suggested that the disorder has a neural basis,

Received 11 January 1974. possibly affecting the autonomic system (Senior and Gellis, 1964; Steinberg and Gwinup, 1967).

We have investigated 6 children and report the results of our studies of carbohydrate and lipid metabolism, and of the functional integrity of the sympathetic nervous system.

\section{Patients}

Four girls and two boys have been studied (Table I). The onset of the disorder occurred between the ages of 5 and 10 years and was insidious in all 6 patients. The extent of the partial lipodystrophy had apparently stabilized when we first studied the children between 1 and 3 years after the onset. No patient was obese over the lower part of the body as judged by clinical examination and skinfold thickness measurement. At this time no other symptoms were present and no patient had evidence of renal disease as judged by urine analyses, blood urea estimations, and intravenous pyelography. There was no other significant history and no family history of lipodystrophy.

\section{Methods}

All patients were initially investigated in hospital, and readmitted at approximately yearly intervals. 4 children had two oral glucose tolerance tests and 2 children (Cases 1 and 5) had 3 tests (glucose $1.75 \mathrm{~g} / \mathrm{kg}$ to a maximum of 
TABLE I

Summary of 6 patients with partial lipodystrophy

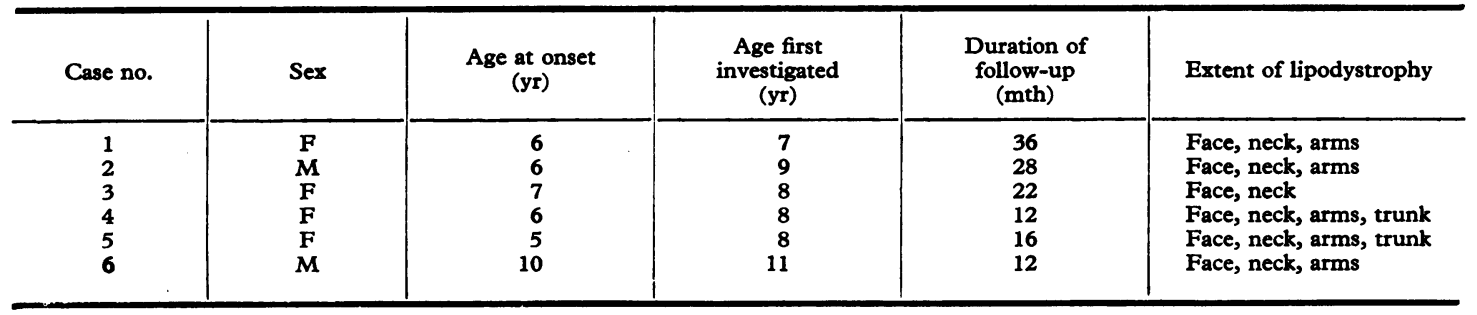

$50 \mathrm{~g}$ ). Venous blood was obtained fasting and after 30, $60,90,120$, and 150 minutes. The data in Tables II, III, IV, and V have been taken from the test in each patient which showed the maximal hyperinsulinaemia.

Plasma glucose was measured by a glucose oxidase autoanalyser technique, serum insulin by a double radioimmunoassay (Grant, 1967), and growth hormone by radioimmunoassay (Jackson, Grant, and Clayton, 1968). Normal values for serum insulin in children after a similar glucose load were taken from the data of Martin and Martin (1973), which agree well with other published data (Parker et al., 1968). Plasma cortisol and cortisol production rate were estimated as described by Barnes $e t$ al. (1972).

Blood for lipid analysis was obtained after a 12-hour overnight fast. Serum cholesterol concentration was measured using a ferric chloride autoanalyser technique (Fosbrooke and Pringle, 1970); the concentration and fatty acid composition of NEFA and serum triglyceride were determined by gas-liquid chromatography, using an internal standard (Fosbrooke and Tamir, 1968). Adipose tissue was obtained by needle biopsy of buttock fat, and after extraction the triglyceride fatty acid composition was determined as for serum triglyceride. Postheparin lipolytic activity was determined according to the method of Fredrickson, Ono, and Davis (1963). Statistical comparisons of results were made using Student's ' $t$ ' test.

\section{Results}

\section{Metabolic studies.}

Insulin. A total of 17 estimations were made in the fasting state in the 6 children, all of whom had at least 2 determinations. The mean value for each child was higher than the mean for normal children reported from the same laboratory (Grant, 1967). The mean value in the patients was $18 \cdot 5 \pm 6 \cdot 0$ ( 1 SD) $\mu \mathrm{U} / \mathrm{ml}$, which is significantly higher $(\mathbf{P}<0.01)$ than the mean of $8 \mu \mathrm{U} / \mathrm{ml}$ for normal children.

Serum insulin concentrations after oral glucose showed hyperinsulinaemia ( $>2 \mathrm{SD}$ above the mean normal value) at some stage in 4 children. The insulin concentrations during the glucose tolerance tests in which maximal hyperinsulinaemia was found are shown in Table II; the mean value at each time is significantly increased. There was no evidence for increasing hyperinsulinaemia with duration of the disease. In the 2 patients who each had 3

TABLE II

Serum insulin during glucose tolerance tests

\begin{tabular}{|c|c|c|c|c|c|c|c|}
\hline \multirow[b]{2}{*}{$\begin{array}{l}\text { Minutes after } \\
\text { oral glucose }\end{array}$} & \multicolumn{7}{|c|}{ Serum insulin $(\mu \mathrm{U} / \mathrm{ml})$} \\
\hline & 0 & 30 & 60 & 90 & 120 & 150 & 180 \\
\hline $\begin{array}{c}\text { Case no. } \\
1 \\
2 \\
3 \\
4 \\
5 \\
6 \\
\end{array}$ & $\begin{array}{l}29 \\
14 \\
11 \\
13 \\
21 \\
24\end{array}$ & $\begin{array}{r}290 \\
77 \\
53 \\
97 \\
160 \\
81\end{array}$ & $\begin{array}{r}20 \\
66 \\
159 \\
63 \\
110 \\
77\end{array}$ & $\begin{array}{r}24 \\
66 \\
154 \\
72 \\
114 \\
73 \\
\end{array}$ & $\begin{array}{l}75 \\
60 \\
57 \\
54 \\
94 \\
39\end{array}$ & $\begin{array}{l}68 \\
80 \\
70 \\
26 \\
88 \\
29\end{array}$ & $\begin{array}{l}= \\
\bar{z} \\
=\end{array}$ \\
\hline $\begin{array}{l}\text { Mean } \pm 1 \text { SD } \\
\text { Mean } \pm 1 \text { SD for } \\
\text { normal children* } \\
P\end{array}$ & $\begin{array}{c}19 \pm 7 \\
6 \pm 4 \\
<0 \cdot 001\end{array}$ & $\begin{array}{r}126 \pm 88 \\
50 \pm 27 \\
<0 \cdot 001\end{array}$ & $\begin{array}{l}82 \pm 47 \\
43 \pm 33 \\
<0 \cdot 05\end{array}$ & $\begin{array}{l}84 \pm 45 \\
42 \pm 22 \\
<0 \cdot 01\end{array}$ & $\begin{array}{l}63 \pm 19 \\
37 \pm 22 \\
<0 \cdot 05\end{array}$ & $\begin{array}{c}60 \pm 26 \\
=\end{array}$ & $\begin{array}{c}- \\
16 \pm 13\end{array}$ \\
\hline
\end{tabular}

^Martin and Martin, 1973. 
TABLE III

Plasma glucose during glucose tolerance tests

\begin{tabular}{|c|c|c|c|c|c|c|c|}
\hline & \multicolumn{7}{|c|}{ Plasma glucose $(\mathrm{mg} / 100 \mathrm{ml})$} \\
\hline $\begin{array}{l}\text { Minutes arter } \\
\text { oral glucose }\end{array}$ & 0 & 30 & 60 & 90 & 120 & 150 & 180 \\
\hline $\begin{array}{c}\text { Case no. } \\
1 \\
2 \\
3 \\
4 \\
5 \\
6\end{array}$ & $\begin{array}{l}62 \\
60 \\
80 \\
67 \\
82 \\
85\end{array}$ & $\begin{array}{r}110 \\
90 \\
125 \\
189 \\
148 \\
144\end{array}$ & $\begin{array}{r}108 \\
76 \\
155 \\
136 \\
148 \\
126\end{array}$ & $\begin{array}{r}89 \\
91 \\
133 \\
116 \\
133 \\
114\end{array}$ & $\begin{array}{r}84 \\
79 \\
106 \\
90 \\
112 \\
96\end{array}$ & $\begin{array}{r}81 \\
98 \\
112 \\
61 \\
103 \\
85\end{array}$ & $\frac{-}{-}$ \\
\hline $\begin{array}{l}\text { Mean } \pm 1 \text { SD } \\
\text { Mean } \pm 1 \text { SD for } \\
\text { normal children* } \\
P\end{array}$ & $\begin{array}{c}73 \pm 11 \\
78 \pm 11 \\
\text { NS }\end{array}$ & $\begin{array}{l}134 \pm 34 \\
114 \pm 19 \\
\text { NS }\end{array}$ & $\begin{array}{l}125 \pm 29 \\
104 \pm 22 \\
\text { NS }\end{array}$ & $\begin{array}{c}113 \pm 19 \\
93 \pm 22 \\
<0.05\end{array}$ & $\begin{array}{l}94 \pm 13 \\
90 \pm 16 \\
\text { NS }\end{array}$ & $\begin{array}{c}90 \pm 18 \\
- \\
-\end{array}$ & $\begin{array}{c}- \\
75 \pm 16\end{array}$ \\
\hline
\end{tabular}

^Martin and Martin, 1973.

TABLE IV

Serum growth hormone during glucose tolerance tests

\begin{tabular}{|c|c|c|c|c|c|c|}
\hline \multirow{2}{*}{$\begin{array}{l}\text { Minutes after } \\
\text { oral glucose }\end{array}$} & \multicolumn{6}{|c|}{ Serum growth hormone $(\mu \mathrm{U} / \mathrm{ml})$} \\
\hline & 0 & 30 & 60 & 90 & 120 & 150 \\
\hline $\begin{array}{l}\text { Case no. } \\
1 \\
2 \\
3 \\
4 \\
5 \\
6\end{array}$ & $\begin{array}{r}1 \\
24 \\
24 \\
1 \\
23 \\
6\end{array}$ & $\begin{array}{r}5 \\
3 \\
7 \\
5 \\
21 \\
8\end{array}$ & $\begin{array}{r}1 \\
1 \\
6 \\
7 \\
14 \\
8\end{array}$ & $\begin{array}{r}2 \\
1 \\
5 \\
3 \\
15 \\
3\end{array}$ & $\begin{array}{r}2 \\
7 \\
6 \\
26 \\
17 \\
7\end{array}$ & $\begin{array}{r}5 \\
9 \\
5 \\
10 \\
20 \\
34\end{array}$ \\
\hline $\begin{array}{l}\text { Mean } \pm 1 \text { SD } \\
\text { Mean } \pm 1 \text { SD for } \\
\text { normal children* }\end{array}$ & $\begin{array}{c}13 \pm 12 \\
7 \pm 8\end{array}$ & $\begin{array}{l}8 \pm 6 \\
8 \pm 8\end{array}$ & $\begin{array}{l}6 \pm 5 \\
5 \pm 3\end{array}$ & $\begin{array}{l}5 \pm 5 \\
4 \pm 2\end{array}$ & $\begin{array}{l}11 \pm 9 \\
8 \pm 9\end{array}$ & $\begin{array}{l}14 \pm 11 \\
15 \pm 14\end{array}$ \\
\hline
\end{tabular}

^D. Jackson, personal communication, 1973.

TABLE V

Plasma NEFA during glucose tolerance tests

\begin{tabular}{|c|c|c|c|c|c|c|}
\hline & \multicolumn{6}{|c|}{ Plasma NEFA (mEq/1.) } \\
\hline $\begin{array}{l}\text { Minutes after } \\
\text { oral glucose }\end{array}$ & $\mathbf{0}$ & 30 & 60 & 90 & 120 & 150 \\
\hline $\begin{array}{c}\text { Case no. } \\
1 \\
2 \\
3 \\
4 \\
5 \\
6\end{array}$ & $\begin{array}{c}1.04 \\
0.51 \\
0.22 \\
0.67 \\
-\overline{0.71}\end{array}$ & $\begin{array}{l}0.69 \\
0.59 \\
0.49 \\
0.52 \\
\overline{0.16}\end{array}$ & $\begin{array}{c}0.56 \\
0.39 \\
0.58 \\
0.20 \\
\overline{0.09}\end{array}$ & $\begin{array}{c}0.41 \\
0.85 \\
0.26 \\
0.22 \\
-\overline{0.12}\end{array}$ & $\begin{array}{c}0.42 \\
0.72 \\
0.23 \\
0.20 \\
- \\
0 \cdot 10\end{array}$ & $\begin{array}{c}0.59 \\
0.48 \\
0.22 \\
0.32 \\
- \\
0.08\end{array}$ \\
\hline $\begin{array}{l}\text { Mean } \pm 1 \text { SD } \\
\text { Mean } \pm 1 \text { SD for } \\
\text { normal children }\end{array}$ & $\begin{array}{l}0.63 \pm 0.30 \\
0.85 \pm 0.67\end{array}$ & $\begin{array}{l}0.49 \pm 0.20 \\
0.57 \pm 0.28\end{array}$ & $\begin{array}{l}0.36 \pm 0.22 \\
0.42 \pm 0.29\end{array}$ & $\begin{array}{l}0.37 \pm 0.28 \\
0.35 \pm 0 \cdot 13\end{array}$ & $\begin{array}{l}0 \cdot 33 \pm 0 \cdot 24 \\
0 \cdot 34 \pm 0 \cdot 16\end{array}$ & $\begin{array}{c}0.34 \pm 0 \cdot 20 \\
-\end{array}$ \\
\hline
\end{tabular}

^Parker et al., 1968. 
glucose tolerance tests, hyperinsulinaemia was found on two occasions, though the insulin response was normal on the other occasion. The Fig. illustrates this variation in Case 1.

Glucose. Neither fasting plasma glucose nor the response to oral glucose was grossly abnormal in any patient on any of the occasions tested. In the glucose tolerance tests showing maximal hyperinsulinaemia, however (Table III), the mean values for plasma glucose concentration were all above the mean values for normal children, the difference attaining statistical significance at 90 minutes.

Cortisol. Plasma cortisol concentrations were normal in 5 children, in 2 of whom Synacthen stimulation tests were also normal. In 1 patient (Case 5) levels were low, varying between 0.1 and $7 \cdot 2 \mu \mathrm{g} / 100 \mathrm{ml}$ at $9 \mathrm{a.m}$. (normal $17 \cdot 3 \pm 7 \cdot 8 \mu \mathrm{g} / 100$ $\mathrm{ml}$, mean $\pm 1 \mathrm{SD}$ ), and this child had a slightly low response to Synacthen (from 4.0 to $17 \mu \mathrm{g} / 100 \mathrm{ml}$ ), a low cortisol production rate $\left(5.2 \mathrm{mg} / \mathrm{m}^{2}\right.$ per $24 \mathrm{hr}$; normal $12 \cdot 3 \pm 2 \cdot 8 \mathrm{mg} / \mathrm{m}^{2}$ per $24 \mathrm{hr}$, mean $\pm 1 \mathrm{SD}$ ) and a low plasma ACTH $(<38 \mu \mu \mathrm{g} / \mathrm{ml})$ at a time when the plasma cortisol was $4 \cdot 2 \mu \mathrm{g} / 100 \mathrm{ml}$.

Growth hormone. The results of growth hormone estimations during the glucose tolerance tests are summarized in Table IV. Individuals varied both in their fasting levels and in their response to oral glucose. No consistent abnormality was found.

Lipids. Fasting serum cholesterol, serum triglyceride, and plasma NEFA concentrations were normal in all patients (Tables $\mathrm{V}$ and VI).

The fatty acid composition of the serum tri- glyceride was normal. The fatty acid composition of adipose tissue triglyceride, obtained from nondystrophic areas, was studied in 4 patients, and a significantly increased proportion of palmitoleic acid (C16:1) was found (Table VI). The fatty acid composition of plasma NEFA also showed an increase in palmitoleic acid. Postheparin lipolytic activity, measured in 4 children, was undetectable in 1 , and low in 2 (Table VI).

Function of sympathetic nervous system. 2 patients (Cases 3 and 4) were dusted with quinizarin powder and then warmed under a heat cradle. Sweating occurred over both lipodystrophic and normal areas, and there was no demarcation in intensity of sweating between the two areas.

In 2 patients sweating was stimulated by pilocarpine iontophoresis over normal and lipodystrophic areas simultaneously. The concentration of sweat sodium was similar for both areas in each patient, being 27 and $34 \mathrm{mEq} / 1$. (Case 4) and 31 and $30 \mathrm{mEq} / \mathrm{l}$. (Case 5).

In 1 patient (Case 3) a histamine-induced flare was produced by intradermal histamine over both normal and lipodystrophic areas. The extent of the flare reaction was similar in both sites, suggesting functional integrity of the autonomic nerves in both areas.

Because propranolol has been shown experimentally to inhibit sympathetic mediated lipolysis, the drug was given for a trial period to 2 patients.

Case 2. Propranolol $10 \mathrm{mg}$ four times daily $(1 \cdot 3$ $\mathrm{mg} / \mathrm{kg}$ ) was given for 6 months without benefit as judged by facial appearance, skinfold thickness, or weight velocity. No side effects were observed.

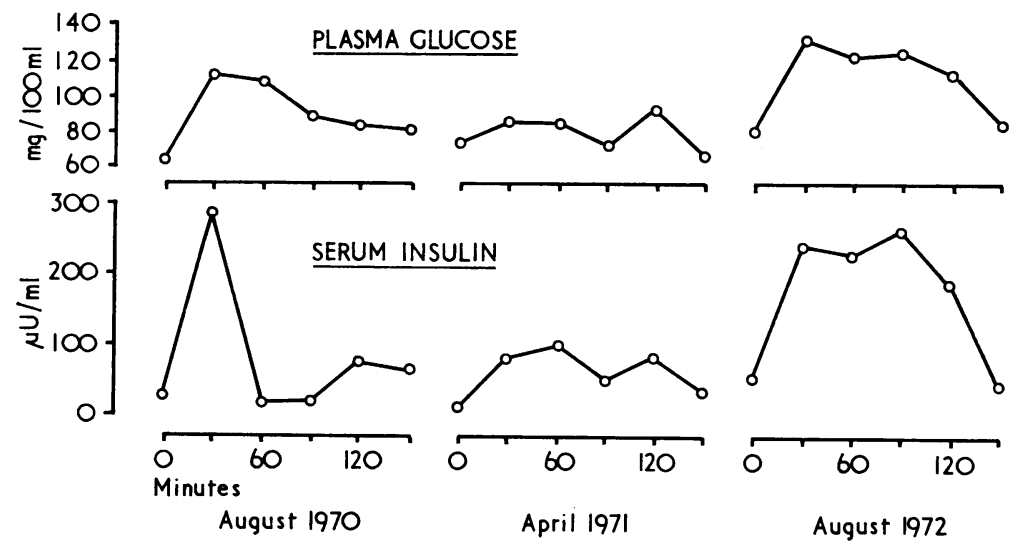

FIG.-Plasma glucose and serum insulin after oral glucose on 3 occasions in Case 1. 
Metabolic studies and autonomic function in children with partial lipodystrophy

TABLE VI

Fasting serum lipids, postheparin lipolytic activity (PHLA), and adipose tissue composition

\begin{tabular}{|c|c|c|c|c|c|c|c|}
\hline \multirow{2}{*}{ Case no. } & \multirow{2}{*}{\multicolumn{2}{|c|}{$\begin{array}{l}\text { Serum cholesterol } \\
(\mathrm{mg} / 100 \mathrm{ml}) \text { mean of } \\
\text { observations (no.) }\end{array}$}} & \multirow{2}{*}{\multicolumn{2}{|c|}{$\begin{array}{l}\text { Serum triglyceride } \\
(\mathrm{mg} / 100 \mathrm{ml} \text { ) mean of } \\
\text { observations (no.) }\end{array}$}} & \multirow{2}{*}{$\begin{array}{l}\text { Plasma PHLA fatty } \\
\text { acid } \\
\text { (mEq/ml per min) } \\
\text { observations (no.) }\end{array}$} & \multicolumn{2}{|c|}{$\begin{array}{l}\text { Palmitoleic acid content }(\mathrm{g} / 100 \mathrm{~g}) \text { total } \\
\text { fatty acid }\end{array}$} \\
\hline & & & & & & $\begin{array}{l}\text { Nondystrophic } \\
\text { adipose tissue }\end{array}$ & Plasma NEFA \\
\hline $\begin{array}{l}1 \\
2 \\
3 \\
4 \\
5 \\
6\end{array}$ & $\begin{array}{l}188 \\
216 \\
191 \\
198 \\
175 \\
233\end{array}$ & $\begin{array}{l}(5) \\
(5) \\
(2) \\
(2) \\
(2) \\
(2)\end{array}$ & $\begin{array}{l}94 \\
77 \\
30 \\
59 \\
37 \\
52\end{array}$ & $\begin{array}{l}(5) \\
(4) \\
(2) \\
(2) \\
(3) \\
(3)\end{array}$ & $\begin{array}{l}0.37 \\
0.20 \\
- \\
- \\
\text { No activity (1) } \\
0.11\end{array}$ & $\begin{array}{l}\frac{11 \cdot 0}{8 \cdot 8} \\
\frac{-}{11 \cdot 5} \\
10 \cdot 0\end{array}$ & $\begin{array}{r}8 \cdot 3 \\
8 \cdot 3 \\
6 \cdot 7 \\
6 \cdot 5 \\
6 \cdot 1 \\
12 \cdot 3\end{array}$ \\
\hline $\begin{array}{l}\text { Mean } \pm 1 \mathrm{SD} \\
\text { Normal } \\
\quad \text { mean } \pm 1 \mathrm{SD}\end{array}$ & $\begin{array}{l}200 \\
192\end{array}$ & & $\begin{array}{l}58 \\
46\end{array}$ & & - & $\begin{array}{l}10 \cdot 3 \pm 1 \cdot 2 \\
6 \cdot 1 \pm 1 \cdot 4 \ddagger\end{array}$ & $\begin{array}{l}8 \cdot 0 \pm 2 \cdot 3 \\
5 \cdot 4 \pm 1 \cdot 3^{\star}\end{array}$ \\
\hline
\end{tabular}

*Our data for normal children.

†Fredrickson et al. (1963), 41 adults.

$\ddagger$ Brook, 1971.

Case 5. Propranolol $10 \mathrm{mg}$ three times daily $(1 \cdot 0$ $\mathrm{mg} / \mathrm{kg}$ ) was given for 3 months, after which the dose was doubled. 2 months later she had sudden onset of gross ascites and right pleural effusion after a 2-week history of vague abdominal pain and slight diarrhoea. Propranolol was immediately discontinued. Investigation did not reveal a cause for the ascites which resolved spontaneously after about a week. No beneficial effect of propranolol had been observed over the 5-month period of its administration.

\section{Discussion}

Hyperinsulinaemia, both in the fasting state and after glucose, has been reported previously in adults with partial lipodystrophy (Steinberg and Gwinup, 1967; Piscatelli, Vieweg, and Havel, 1970; Boucher et al., 1973). Our study of children shows hyperinsulinaemia at an early stage of the disease and this did not apparently increase with the duration of the disease, at least during a relatively short (up to 3-year) period. The intermittent nature of the hyperinsulinaemia in 2 of our patients cannot be explained, but it is not accounted for by intercurrent illness, gross change of dietary habit, or change of growth rate.

The normal plasma glucose concentrations in the presence of hyperinsulinaemia indicate some degree of insulin resistance. Of the possible explanations for this insulin resistance neither obesity in the nondystrophic areas, nor increased plasma cortisol, nor excess growth hormone can be implicated in our patients. In fact the patient in our series (Case 5) who had low plasma cortisol concentrations also showed marked hyperinsulinaemia. Hyperinsulinaemia has also been associated with increased adipose cell size (Salans, Knittle, and Hirsch, 1968; Stern et al., 1972); no studies of cell size in partial lipodystrophy have yet been reported. Boucher et al. (1973) found no gross abnormality of circulating insulin, no insulin antibodies, and no delay in the removal of insulin from the circulation. They suggested the hyperinsulinaemia might be due to increased sensitivity of $\beta$-adrenergic sympathetic nerves leading to exaggerated hepatic glycogenolysis. We could not show any abnormality of the sympathetic nervous system, and the failure of propranolol to influence the lipodystrophy in either of our patients, or in the patient of Boucher et al. (1973), makes it unlikely that sympathetic overactivity plays a primary role in the disease.

The development of clinical diabetes mellitus has been reported in about $20 \%$ of adult patients (Murray, 1952; Rifkind, Boyle, and Gale, 1967). This is presumably a late effect of hyperinsulinaemia, due either to pancreatic $\beta$-cell exhaustion or to increasing insulin resistance.

The increased proportion of palmitoleic acid in triglyceride from adipose tissue in the nondystrophic areas may be explained on the basis of hyperinsulinaemia, insulin having been recognized as a factor which promotes fatty acid desaturation (Brenner, 1971). We have observed similar increases in palmitoleic acid in adipose tissue from obese children (Fosbrooke, Brook, and Lloyd, 1971) who also have hyperinsulinaemia.

The fasting plasma NEFA concentration in our patients is normal and the increased content of palmitoleic acid suggests that, at least in part, it is derived from the nondystrophic adipose tissue. It is not known if any of the NEFA is derived from dystrophic areas. That NEFA may arise from 
dystrophic tissue in total lipodystrophy has been shown by Senior and Loridan (1969). The lowering of plasma NEFA concentration on feeding glucose suggests that lipolysis is readily suppressible.

Hypertriglyceridaemia has been reported as a consistent feature in adults with partial lipodystrophy by Rifkind et al. (1967) and by Piscatelli et al. (1970). Our finding of normal serum triglyceride concentrations in children shows that hypertriglyceridaemia is not an integral feature of the disorder.

A neuronal abnormality has been postulated to explain the distribution of the dystrophic adipose tissue (Senior and Gellis, 1964; Steinberg and Gwinup, 1967), but there is no other evidence to support this. The definition of Senior and Gellis, while helpful in assuring homogeneity of patients studied, does tend to exclude patients whose dystrophy does not follow a nerve root pattern, but in whom the basic defect may well be the same.

Immunological studies have recently been undertaken because of the association between partial lipodystrophy and nephritis, and abnormalities of serum complement have been shown even in patients who do not have nephritis (Peters et al., 1973; Thompson and White, 1973). Further studies are needed to clarify the significance of immunological abnormalities in partial lipodystrophy.

Partial lipodystrophy has often been regarded as primarily a cosmetic disability. The finding of insulin resistance at an early stage and the significant risk of the development of diabetes mellitus and of nephritis indicates that it is a generalized and potentially serious disorder.

We thank Mrs. D. Jackson for the insulin and growth hormone estimations, and Professor O. H. Wolff and Drs. H. Fisher, K. R. Norton, F. W. Nash, S. D. V. Weller, and $R$. Wigglesworth for allowing us to investigate their patients.

\section{REFERENCES}

Barnes, N. D., Joseph, J. M., Atherden, S. M., and Clayton, B. E. (1972). Functional tests of adrenal axis in children with measurement of plasma cortisol by competitive protein binding. Archives of Disease in Childhood, 47, 66.

Boucher, B. J., Cohen, R. D., Frankel, R. J., Stuart Mason, A., and Broadley, G. (1973). Partial and total lipodystrophy: changes in circulating sugar, free fatty acids, insulin and growth hormone following the administration of glucose and of insulin. Clinical Endocrinology, 2, 111.

Brenner, R. R. (1971). The desaturation step in the animal biosynthesis of polyunsaturated fatty acids. Lipids, 6, 567.

Brook, C. G. D. (1971). Composition of human adipose tissue from deep and subcutaneous sites. British fournal of Nutrition, 25, 377.

Eisinger, A. J., Shortland, J. R., and Moorhead, P. J. (1972). Renal disease in partial lipodystrophy. Quarterly fournal of Medicine, 41, 343.

Fosbrooke, A. S., Brook, C. G. D., and Lloyd, J. K. (1971). Plasma lipids in obese children treated with $350 \mathrm{Kcal}$ diets. Postgraduate Medical fournal, 47, (June Suppl. 1971), 444.

Fosbrooke, A. S., and Pringle, G. A. (1970). Improved precision for the autoanalyser determination of serum cholesterol. Clinica Chimica Acta, 30, 47.

Fosbrooke, A. S., and Tamir, I. (1968). A modified method for the preparation of methyl esters of a mixture of medium-chain and long-chain fatty acids. Clinica Chimica Acta, 20, 517.

Fredrickson, D. S., Ono, K., and Davis, L. L. (1963). Lipolytic activity of post-heparin plasma in hyperglyceridemia. fournal of Lipid Research, 4, 24.

Grant, D. B. (1967). Fasting serum insulin levels in childhood. Archives of Disease in Childhood, 42, 375.

Jackson, D., Grant, D. B., and Clayton, B. E. (1968). A simple oral test of growth-hormone secretion in children. Lancet, 2, 373.

Langhof, H., and Zabel, R. (1960). On lipodystrophia progressiva. Archiv für Klinische und Experimentelle Dermatologie, 210, 313.

Martin, M. M., and Martin, A. L. A. (1973). Obesity, hyperinsulinism, and diabetes mellitus in childhood. fournal of Pediatrics, 82, 192.

Murray, I. (1952). Lipodystrophy. British Medical fournal, 2, 1236.

Parker, M. L., Pildes, R. S., Chao, K-L., Cornblath, M., and Kipnis, D. M. (1968). Juvenile diabetes mellitus, a deficiency in insulin. Diabetes, 17, 27.

Peters, D. K., Gwyn Williams, D., Charlesworth, J. A., BoultonJones, J. M., Sissons, J. G. P., Evans, D. J., Kourilsky, O., and Morel-Maroger, L. (1973). Mesangiocapillary nephritis, partial lipodystrophy, and hypocomplementaemia. Lancet, 2, 535.

Piscatelli, R. L., Vieweg, W. V. R., and Havel, R. J. (1970). Partial lipodystrophy. Annals of Internal Medicine, 73, 963.

Rifkind, B. M., Boyle, J. A., and Gale, M. (1967). Blood lipid levels, thyroid status, and glucose tolerance in progressive partial lipodystrophy. Fournal of Clinical Pathology, 20, 52.

Salans, L. B., Knittle, J. L., and Hirsch, J. (1968). The role of adipose cell size and adipose tissue insulin sensitivity in the carbohydrate intolerance of human obesity. Fournal of Clinical Investigation, 47, 153.

Senior, B., and Gellis, S. S. (1964). The syndromes of total lipodystrophy and of partial lipodystrophy. Pediatrics, 33, 593.

Senior, B., and Loridan, L. (1969). Fat cell function and insulin in a patient with generalized lipodystrophy. Fournal of Pediatrics, 74, 972.

Steinberg, T., and Gwinup, G. (1967). Lipodystrophy, a variant of lipoatrophic diabetes. Diabetes, 16, 715.

Stern, J. S., Batchelor, B. R., Hollander, N., Cohn, C. K., and Hirsch, J. (1972). Adipose-cell size and immunoreactive insulin levels in obese and normal-weight adults. Lancet, 2, 948.

Thompson, R. A., and White, R. H. R. (1973). Partial lipodystrophy and hypocomplementaemic nephritis. Lancet, 2, 679.

Correspondence to Dr. R. J. West, Institute of Child Health, 30 Guilford Street, London WC1N 1EH. 